\title{
Silence is Golden. Lessons from a Traumatized Field ${ }^{1}$
}

\author{
Gabriella Tuboly-Vincze \\ PhD candidate - University of Pécs, Ethnology and Cultural Anthropology Doctoral Program, \\ Interdisciplinary Doctoral School, Pécs
}

\begin{abstract}
Relying on the experiences of my fieldwork carried out in the town of Jedwabne in Poland, my article investigates the way in which a deeply traumatized field potentially makes anthropological inquiry impossible, and the methodological and ethical problems researchers face both in the course of fieldwork and while processing, analyzing, and making the knowledge gained through research public. The first part briefly introduces the small town of Jedwabne, the conflict that drew me to this place, and the research project, which I believed I was never going to be able to write about. In the second part, I discuss the complex system of taboos that I termed 'the culture of seclusion', which, in my view, is the most typical aspect of the society of Jedwabne, as well as the greatest challenge of my research. As a sort of synthesis of the first two parts, in the third part I consider some practical issues and concerns related to the fieldwork.

Keywords: social trauma, anthropological fieldwork, national identity, traumatic memories, Holocaust, trauma of perpetrators
\end{abstract}

Before I neatly packed up my notes on the eve of going home from my fieldwork, I pondered if the nine plus one and a half months I spent there and the two years of preparation that preceded my journey had made any sense. In the beginning, I naively thought that I would fill thousands of pages with my detailed observations, wear out at least three Dictaphones, take millions of pictures, and come home in possession of knowledge that would let me boldly state: I've been initiated, I've became an anthropologist. Compared to this, there I was, with just a few barely scribbled notebooks, a couple hours of audio material, a bagful of bitterness, and more questions than I came here with.

To a student, it seemed that anthropologists possessed wondrous abilities that allowed them to access the secrets unavailable to everyday mortals - the magic, the sacred, the carefully guarded knowledge. In my thinking at the time, what else would the

\footnotetext{
${ }^{1}$ Hereby I would like to thank all those who have contributed important remarks and suggestions to this study: Ildikó Landgraf, Ildikó Tamás, Zoltán Nagy, and Csaba Mészáros.
} 
ethnographic method be more useful for if not for revealing and interpreting the reality behind the visible culture, in its true light and depth? To see and to understand the invisible threads that drive human behavior. To truly get to know the Other without judgment, without bias. But what if these secrets are simply inaccessible to the researcher, or if they are accessible, they cannot be used in the potential publication? Could a fieldwork be deemed successful if it is admittedly based on only partial information? What can we consider sufficient and relevant information in the context of fieldwork, and generally in anthropological research? So, I would like to write about what I cannot write about, and how the failures and limitations of my fieldwork had still managed to contribute to my relative understanding of the field.

Since Malinowski, one of the main features of anthropology that clearly distinguishes it from any other empirical discipline has been its specific research methodology and fieldwork concept, which simultaneously provides - essentially flexible - methodological frameworks and very serious ethical guidelines (e.g., the concept of cultural relativism, which at once defines the possibilities and boundaries of the research practice itself, as well as the non-judgmental way we can write about "natives"). It works like the societies it examines: there are hardly any rules that are always and everywhere uniformly valid and rigorous, the violation of which could result in disqualification from the profession; rather, there are well-defined norms that define practically everything in anthropological research, albeit with varying intensity and emphasis - these are ethical (do no harm, be loyal, avoid judgment, etc.), ${ }^{2}$ and, in a narrower sense, methodological (do not be a native, live there, speak the language, interview, document everything, etc.) guidelines. ${ }^{3}$ This includes the fact that, because every field requires different competencies, different behavioral patterns, and sets different challenges for the researcher, the relatively flexible methodological norms of anthropology take a specific shape according to the norms of the field, and thus it is the field that shapes the actual practice (therefore we cannot talk about a completely uniform and rigorous research methodology). The greatest difficulty and beauty of fieldwork lies exactly in the fact that researchers, relying primarily on two major standards, those of the anthropologist-society and those of the society being studied, and trusting their intuition, must decide how they are going to do their work. ${ }^{4}$

\footnotetext{
${ }^{2}$ These guidelines are from the Ethics Code of the American Anthropological Association. Available at: http://www.americananthro.org/ParticipateAndAdvocate/Content.aspx?ItemNumber $=1656$

${ }^{3}$ It must be added that the definition of the purpose and realization of anthropological/ethnographic fieldwork is obviously not so unambiguous and simple, since, like all disciplines, ours also needs to refine working methods, reconsider sources, data used, necessary knowledge, and so on, according to current goals (see MÉSZÁros - VARGYAs 2016 for more information on the issue). This, however, does not mean that there is no relatively stable framework within which the work method can be updated, reconsidered, and implemented. I tried to refer to this with the simplified scheme I described.

${ }^{4}$ Napoleon Chagnon's book (Noble Savages: My Life Among Two Dangerous Tribes - the Yanomamö and the Anthropologists), for example, is built upon this duality, and addresses the history of the controversial Yanomamö research as illustrated through Chagnon's professional career (CHAGNON 1968, 2014). An impressive collection of more personal accounts that reflect on the human, emotional aspect of ethnographic and/or anthropological fieldwork and the researcher's position was published by Csaba Mészáros and Gábor Vargyas (Mészáros - Vargyas 2016). The most important texts for this study are: Régi 2016; SÁNTHA 2016; VARgYas 2016; and from the next issue: NAGY 2017.
} 
Through a highly sensitive topic, this study illustrates how the researcher negotiates these different expectations and rules.

I also think that I'm not exaggerating, and maybe not even saying anything new, when I say that, like many other disciplines, anthropology also handles countless methodological issues as a very serious moral issue, which also means that field-specific ethical problems often become methodological dilemmas that also define the fieldwork and the afterlife of the research. Because of this, (anthropological) research can become more difficult if we want to say something about a deeply traumatized ${ }^{5}$ society - something that more than just scratches the surface, something that does not cause pain to those studied, and something that may still be interesting and relevant for anthropology.

In the following, my study addresses the above-mentioned issues in three parts. In the first, I briefly present Jedwabne: the small town where I was doing my fieldwork; the conflict situation that aroused my interest and led me to Jedwabne; and the research whose results I thought I was never going to be able to write about in any form. In the second part, I address the complex system of taboos, which I refer to as a culture of seclusion, which is the most characteristic aspect of Jedwabne's society in my opinion, and the greatest challenge of my research. In the third and last part, recapitulating the foregoing, I hash out some questions about the practical issues and concerns encountered during fieldwork.

\section{THE FIELD - JEDWABNE}

The town of Jedwabne is a settlement of nearly 2,200 souls in the northeastern corner of Poland, in Łomża County of Podlaskie Province. My research has been ongoing since the end of 2010; I have been following events and publications related to Jedwabne since then, and my fieldwork in the traditional sense was carried out in July 2012 and between May and December 2013. During the period I spent there, I lived with the same local family, and they were actually the ones who assisted me most in my integration, social introductions, orientation, and language-learning process. And due to us living together, it was naturally this family in Jedwabne that I got to know best, and most of those I talked to (especially in the first months) came from their narrower network. In the second half of my fieldwork, building upon these relationships, among other things, I started contacting others who eventually participated in identifying the different directions of my research.

All in all, I managed to interview 62 local people in the course of (one or more) semi-structured or spontaneous conversations. At the request of my communicators, most of these conversations were not recorded in any way. Most of my acquaintances

\footnotetext{
${ }^{5}$ What I consider a traumatized society will be addressed later, but within the framework of this study, I have no opportunity to talk about it in detail. The concept of trauma that is closest to the one used in this paper is the concept of cultural trauma put forward by Jeffrey C. Alexander. See Alexander 2004, 2012; GYÁNI 2012.
} 
were middle-aged women and newcomers: ${ }^{6}$ They were the ones who were least guarded about talking to me and considered my presence the least "dangerous". However, I tried to build my relationships so as all ages would be actually represented: my youngest conversation partner was 16, the oldest was 89 years old. There have been attempts to talk with children, but these, as we will see later, were quite obviously futile endeavors.

In addition to the interviewing method, participant observation, which is another trademark of anthropology, was the main resource for my research. I tried to join as many events that structured everyday life as possible (working around the house, going to the market, mushrooming, going to church), and attending local (political, church, city) events. In addition to the latter, I attended the national commemoration in the Jedwabne Memorial Park on two occasions (2012 and 2013), ${ }^{7}$ and, as far as I was able to do so, I tried to talk to the keepers of the public discourse, too. This is how I got to interview a performance artist from Warsaw, ${ }^{8}$ several journalists, politicians, and researchers, as well as the leaders of various Jewish religious and civil organizations. All in all, however, it can be said that it was not primarily the things said in the interviews that facilitated the present study, but, in its own way, the knowledge gleaned from beyond the conversations that was difficult or virtually impossible to access.

\section{THE JEDWABNE DEBATE}

With the advent of the $21^{\text {st }}$ century, the history of the town of Jedwabne came to a turning point which, according to local narratives, fundamentally changed the lives of the residents; it has earned a special place in the political, public, and historiographical interest of the last one and a half decades, in both domestic and international arenas. This prominent attention is due primarily to the 2001 micro-historical monograph by Jan Tomas Gross (Neighbors: The Destruction of the Jewish Community in Jedwabne, Poland) (Gross 2001). According to the description in the book, on July 10, 1941, Jedwabne was the scene of a brutal vigilante pogrom during which the entire Jewish population of the settlement (1,600 people, according to the book) was slaughtered - most of them were burned to death in the barn of a local family. The reason this work triggered a tremendous debate later on was the author's assertion that the string of murders was initiated by the local Catholic Poles of their own volition, without any outside (German) help. Gross' stated purpose was to revise Polish national memory, because, in his view, the Holocaust could not have happened without the involvement

\footnotetext{
${ }^{6}$ By newcomers, I refer to the local residents who moved to Jedwabne after the end of the Second World War, and more specifically, the local residents who are considered by the local society to be newcomers.

${ }^{7}$ Following the eruption of the debate, the Jedwabne State Memorial Park was set up under the direction of the staff of the Instytut Pamięci Narodowej (Institute of National Remembrance) at the site of the former mass grave, next to the old Jewish cemetery. Every year, the anniversary of the pogrom is commemorated.

${ }^{8}$ Rafał Betlejewski, whose project Płonie Stodoła (Burning Barn) was his first involvement in the public remembrance (BETLEJEWSK 2010). An account of the event can be found at the following link: https://www.youtube.com/watch?v=r21Jur404Lo
} 
of ordinary Polish people. According to this, the most urgent task of the Polish people is to cleanse (KACZINSKI 2000) their national memory of false historical myths and take responsibility for the great Polish tragedies of the $20^{\text {th }}$ century.

Almost instantly, these statements sparked a tremendous scientific and public debate in Poland, and in the public discourse on Jedwabne that is still ongoing, the pogrom figures as a national trauma - a symbol of a cataclysm suggesting that after centuries of victimization, the Poles have become the executioners. The official political stance placed the responsibility on the contemporary population of Jedwabne, and expected exoneration from them, too. ${ }^{9}$ However, today's population of Jedwabne (apart from a few oppositions early on) completely refuses to engage in the public discourse or in the work of the official remembrance. And because the Jedwabne dilemma has from time to time become the subject of lively public discourse over the past one and a half decade, the definition of Jedwabnerness and the constant, intensive compulsion for selfreflection have become an integral part of local society. This kind of outward composure, however, is anything but passivity on the part of the people of Jedwabne, and it does not indicate a lack of, say, the remembrance of the pogrom. The outward composure, i.e., the disassociation from the official and public remembrance work, is a very conscious and obligatory behavioral strategy, which I call the culture of seclusion.

\section{THE CULTURE OF SECLUSION}

The challenges of fieldwork can be best explained by two closely related characteristics of local society: the norms of the culture of seclusion that permeate all strata of society, and the process of enculturation that leads to the acquisition of these norms. Just like the locals, the researcher's life in Jedwabne is also determined by her ability to take an approach that is acceptable to the locals. In the following, let's look at what I mean by the obscure expression of the culture of seclusion.

The culture of seclusion - as the most typical aspect of local society, in my opinion is to be interpreted as a complex system of taboos. The issue of taboo plays a prominent role in trauma research, which is not particularly surprising, since it is the process of traumatization: a fabric woven of the various yarns of non-disclosure, evasion, and prohibition, be it personal or social trauma. However, despite it being a key concept, or more specifically a phenomenon, it is not commonly defined. Tabooing usually means "concealment", "non-disclosure", that is, it is specifically treated as a linguistic phenomenon, the main question being: what is not being said and why? In many cases, the explanation of tabooing is often used to justify preconceptions: victims are silent because they are traumatized and are suppressing the traumatic event, and perpetrators because they cannot bear the guilt and are trying to deliberately forget. It may well be obvious then that most texts will have extremely black-and-white participants, and in many cases, only the victims are considered entitled to a traumatized state. It also shows that most research is working with an extremely rigorous, divided image, that is, only the

\footnotetext{
${ }^{9}$ For the reception of the Gross book, see, for example, BiKont 2004; GonTARCZYK 2001; GLOWACKA ZyŁinska 2007; Janowski 2012; Kapralski 2006; Polonsky - Michlic 2004; Wolentarska - Ochman 2006.
} 
victim and the perpetrator of the trauma appear in the texts, and these roles are associated with clear behavioral patterns and moral judgment. ${ }^{10}$

Through the example of Jedwabne, we encounter two pronounced contradictions regarding the above approach. On the one hand, we see that there are both verbal and non-verbal taboos in Jedwabne (this is not unique, of course): a system of forbidden talk topics, prohibited practices, and behavioral rules that reinforce seclusion. On the other hand, we cannot talk explicitly about victims and perpetrators, not the least because we are not talking about the victims and perpetrators of actual actions in the now - this is about victimhood and responsibility in discourses, which are mostly symbolic roles. From the point of view of scientific approach, the above categories are inappropriate if we want to filter out judgment. However, determining who is considered a victim and who a perpetrator in the context of the Jedwabne debate is a matter of perspective. To the public, they are the perpetrators, even if we are talking about mostly descendants, and in many cases, newcomers; that is, everyone who lives in Jedwabne is affected, regardless of their origin. However, from the perspective of the people of Jedwabne, they are the absolute victims, stigmatized by the public, unable to live a happy life because they have been ostracized by Polish society.

The culture of seclusion is such an integral part of the reality created and experienced by the people of Jedwabne that it also affects the most common aspects of everyday life, such as, for example, Internet use, political preferences, land disputes between neighbors, employment, or even formal and informal education. But what exactly is it? Briefly, it is a set of norms, attitudes, categories, practices, and lexical knowledge that define the locals' possibilities and frameworks of contact with the so-called public, the characteristics of a Jedwabner, and which - wittingly or unwittingly - stabilizes the traumatized state caused by the public debate. The term is absolutely an etic category; Jedwabners do not think of it so abstractly, but, in various other forms, they nevertheless do refer from time to time to the presence of a seemingly coherent and evident system.

After the publication of the Gross book, scores of politicians, journalists, reporters, historians, and those wanting to commemorate flooded the small town. This period also

${ }^{10}$ There is little room for discussing these problems in more detail in this study. Nonetheless, as a kind of supplemental information, it is worth mentioning that in the research of trauma, especially of collective trauma, the problems of the scientific studies of the Holocaust were often encountered - it seems that, especially in the beginning, trauma research itself served as an alternative to the scientific and objective analysis of the Holocaust. I think it is important to mention this, because the Holocaust (as a great collective traumatic experience of the $20^{\text {th }}$ century) calls into question again and again the possibilities of representation, analysis, interpretation, etc., at the level of literary or other artistic and scientific representations. In particular, I'm thinking of the central dilemma of whether it is ethical at all to speak of the Holocaust in the dry language of science, and if so, within what framework it should be done. Talking about the Holocaust always involves a dozen moral problems, and trauma research in general is the same, albeit in a somewhat more modest way and with less emphasis. The hegemony of the victims' perspective, among other things, is due largely to this, as well as to the fact that the potential traumatization of the perpetrators is not even considered at all (except for a couple of refreshing exceptions, such as the texts of Éva Kovács and Mary Foolbrook noted in the bibliography). For more on the issue, see Kisantal 2009; Todorov 1980; Heller 2006; Gyáni 2006; Caruth - Felman 1991; Rosenfeld 2010. 
became thematized as a kind of traumatic experience during my many conversations with the locals. One of my conversation partners remembered this period as follows:

\begin{abstract}
"You can't even imagine what it was like here during those times. Jedwabne was a circus, we the clowns and beasts, and our life was the big show, the attraction everyone wanted to see. Everything changed afterward. Since then, you cannot just naturally and lightly say, 'I live in Jedwabne'. Do you understand? We're still part of the show today. They took our lives. You don't feel like this every moment of every day, but when they show something on TV, or when you ask a question - sorry, ma'am, I don't want to insult you, but do you understand or not? then you know that your whole life is different. If you don't think about it and just go to work, or watch your children as they play, or sit in front of the TV, then you don't think about it, but from time to time you will remember it, and you will know that everything is different than it used to be."
\end{abstract}

The people of Jedwabne explain the need for seclusion in many ways, but most importantly with the fact that the debate has changed their lives, they've been separated from the whole of Polish society, and became stigmatized. The above quotation emphasizes this breakpoint aspect, and illustrates the point that while in public memory it is the pogrom that is being traumatized, i.e., the event of the pogrom is the absolute negative breakpoint, for the people of Jedwabne, it is the debate itself and the sense of stigmatization resulting from the debate that gets interpreted as a collective trauma.

The category of public in Jedwabne is closely related to this problem. To the locals, the public is actually a homogeneous set (as are the locals to the public), which includes everyone that is not from Jedwabne, regardless of political orientation, and who - for lack of knowing the so-called authentic and true history that the locals heard from their parents and grandparents, that is, the authentic eyewitnesses - think of the locals as monsters. According to the people of Jedwabne, isolation and seclusion are necessary in this changed life situation because they cannot and do not want to meet the expectations of the public, i.e., to take responsibility for the events of ' 41 .

At this point, I think it is worth briefly talking about what one's personal knowledge means in its conflict with the public. During my fieldwork in Jedwabne, I met no locals who did not refer in some way to the tensions between different recollections, and thereby to their differential status within Polish society. What one says about this, and the exact reasons one sees behind this is, in my experience, closely related to the information one has about the public narratives and events regarding Jedwabne. Of course, this covers a wide range of knowledge. I met only a few people in Jedwabne that had read the Gross book that sparked the debate, and, in my experience, the material of the debate is not very well known either. They only reflect on events in which they are unable to avoid direct or indirect contact with the public. Overall, it can be said that they cannot completely filter out the influx of news, but, according to their own admission, they are rarely discussed, so there is no uniform knowledge about the public discourse either. This is at once a natural and conscious decision: they do not let in the public's - in their opinion - monophonic history of Jedwabne, and at the same time try to avoid the emergence of an internal monophonic canon.

The vast majority of Jedwabners believe that authentic and true history can only be learned from authentic informants, that is, from their own ancestors who have their own 
history of the pogrom, from their own perspective. For this reason, in Jedwabne, we can only encounter the story of the pogrom in the genre of family history. This does not mean, of course, that there are no representative types of these narratives. Here are some examples:

1. "There were Germans here, two of them, they had large weapons, and they walked from house to house. They told the Poles that if they did not kill the Jews, they would kill their entire family before their eyes. You know, everyone was very scared, everyone wanted to protect their children and wives. Many went out into the street with the Germans, but by then the Laudanski brothers were there, one with a knife, the other with a rifle, and there were many, many transgressors there. They killed everyone, those few people. They were not even human. They were villains. Animals. But the others were scared. They feared for their families. They didn't do anything. They just watched the Jews."

2. "Everyone talks about the Jedwabners, even though they didn't do anything. You know, those days, there were murders like that everywhere. The killers were the same everywhere: Poles, allegedly Catholics, who said they deserved it because they killed Jesus. And they went from village to village, and forced good Catholics everywhere to kill, or to watch the horrors. They say many were wailing, everyone was crying and praying for it to end and not have to see it. That's what my grandmother said, she was a little girl then."

3. "My grandfather hid the shoemaker because he said he was always so kind to him, he always worked well, he didn't cheat, and he loved his family, too. But when the Germans noticed this, they shot him in the leg and beat him until he passed out. He almost died, even though he just wanted to help. No one told you about this, did they? Journalists are not talking about this. But there were heroes here, too. Great heroes."

The local historical narratives I know of are fundamentally diverse and focus on individual families, but they are generally consistent in the following: the pogrom did happen, it happened on the day that Gross wrote, all the local Jewish people were massacred, and there were people from Jedwabne among the wrongdoers. But the greatest unity lies in the question of responsibility: it is either the Germans, or nearby Poles, or locals who are considered criminals that are labeled as transgressors.

"My grandfather told me that the Germans were the killers. There were also men from Radziłów, and the Ramotowskis from Jedwabne, who were all criminals. Tell me you don't believe the many lies Gross tells! I prefer to believe my grandfather."

All this primarily reveals the different interpretations of official and local history, rather than the divergence of the details recounted as facts. And if the two images of history are incompatible with each other, then it is not possible for the responses to them to be the same either. That is, if the official history emphasizes the collective and exclusive guilt of Jedwabne, as it sort of does, it is logical that it expects a collective assumption of responsibility from the people of Jedwabne. However, if local historical memory credits a couple of criminals and the Germans for the massacre, there is actually no reason for the town's population to apologize for anything. Thus, the culture of seclusion is 
also legitimized at the narrative level by making a distinction between true and false histories: while they believe that the public demands their taking responsibility on the basis of false history, what they consider true history, however, does not justify this.

In Jedwabne, we cannot really count on the open conflict between different (pogromrelated) memories. This may be because, for example, there is no resident in Jedwabne who would be a credible representative of a potential counter-memory work. Anyone who could have been had either been banished (e.g., the last living named wrongdoer, after the eruption of the debate), or assimilated (e.g., a Jewish woman who became "Polish" by marrying a local Catholic man right before the pogrom and was thus the only formerly Jewish resident of Jedwabne until her death in 2012), or simply no longer lives. We cannot say with complete certainty, however, that everyone in Jedwabne is uniformly spreading the historical narratives defined by local norms: I have met with a number of locals who have assured me of their absolute disinterest and lack of opinion regarding the subject, but also someone who - as I found out after my departure - was believed to espouse antisemitic views if he could do so. Nonetheless, although real emotions, knowledge, and opinions may be differentiated in the private sphere, in the local public sphere, to which I have access, they only speak and act in accordance with the rules of the culture of seclusion. If anyone were to violate the norm, they can expect to be punished by the community according to their social status - the mayor may be deposed prematurely, the priest may be banned from going to mass, an average local resident may be permanently marginalized, and a child or an newcomer might be gently steered onto the right path.

Based on all of the above, it may already be evident that the culture of seclusion is the absolute determinant of all that is the cultural essence of Jedwabnerness, and although it is based on a special traumatization process, it is not its destructive aspects that dominate. In fact, the example of Jedwabne shows that the trauma narrative of "the public as a common enemy" actually creates a real or imagined community for the people of Jedwabne.

\section{BEING A JEDWABNER, BECOMING A JEDWABNER}

Nothing illustrates better just how determining all this is than the process of learning about and being initiated into the local culture - when the most important rules of seclusion become obvious and explicit. In order to become a true Jedwabner, one must master the rules, behavioral patterns, norms, and social/cultural/historical knowledge of living in the culture of Jedwabne. The extent and quality of the cultural capital of Jedwabnerness one owns can differentiate the local society in many ways. On the one hand, they draw Jedwabne's external symbolic boundaries by distinguishing the public from Jedwabners, and on the other hand, from the inside, by distinguishing the true Jedwabners from the "uninformed". The "uninformed" category here refers to two emic sub-categories: children and newcomers.

Although children and newcomers seem to be equally uninformed in the eyes of the locals and have to be taught the rules of living in Jedwabne, there is in fact a remarkable difference between them in both consideration and the enculturation process. The experience of my fieldwork so far shows that when, where, and in what form they 
are initiated into the history of the small town is an integral part and an important stage in the socialization of children in Jedwabne. The task of initiation falls upon the family, because, as the locals say, specific family histories can only be truly known by the specific family. The school is an official institution that, in their view, may have the right to expropriate history, but parents protest that. In Poland, as part of history education, teachers are supposed to provide an opportunity for children to hear about the local aspects of historical events discussed in the classroom. My younger conversation partners, as well as the teachers I interviewed, say that the subject of the Holocaust in this case is completely left out of the curriculum. In an interview, one of the local teachers justified this by saying that the school was responsible for teaching about pride, not stigmatization. There are individual family stories here, individual ideas about the debate, and the parents need to determine what the child can know; they cannot confuse them with objective information from external sources. The initiation has a dual purpose: to face the possible sins of the ancestors and to process it (if there are any), and, on the other hand, to prepare for the public attacks and how to react appropriately. ${ }^{11}$

In Jedwabne, the initiation of newcomers into both the pogrom and the specific history of the debate is of paramount importance, and in a manner, that does not undermine the stability of the culture of seclusion. In this, it resembles the process of the enculturation of children. However, what makes the position of newcomers special is the fact that they are actually a potential source of danger in the town; after all, they are coming from the public without, equipped with the public's category system, false information and opinion, and can return there at any time. That is why it is important that they not only learn but also accept the legitimacy of local norms, as they must override their supposed value judgments and preconceptions with those of the native Jedwabners. ${ }^{12}$

There is a remarkable difference between the initiation of children and newcomers: while in the case of children, the primary explicit purpose of the locals is to protect the children, in the case of newcomers, what dominates is the protection of the community. Children are the ones, who can potentially be accused by their ancestors, but in the case of newcomers, we are talking about a quasi-chosen identity; for them, it is not the legacy of

${ }^{11}$ From an interview: "I have to tell them about this, and so does their father. But rather their father, because I was not born here. But I also had to learn to live with it, and, you know, it was very difficult, even though I was an adult already. This is such a terrible event, children shouldn't even watch it on TV. And we must talk about it. But they can't hear it from anyone else, only from their father, because he can tell them not to believe the lies, because his grandparents were good people, and whatever they may say, he is a good man, too. It is what you do now that makes you a good person, not what your ancestors did long ago. They must know this, and they must love their grandparents, too, otherwise they will suffer throughout their lives from what others think about them. They must learn to carry this burden, and they must also learn how to respond if/when they or their families are being hurt/ insulted."

12 "I was afraid to move here first. I knew my partner was a good man, but there was so much talk, and one can read so many bad things, I did not know what to think. I was afraid of people, and also that I would become like them. Or, if I become a resident of Jedwabne, they will think the same of me as they think of them. We talked a lot about this at that time. My husband said that there will certainly be strange looks, but I shouldn't mind them because they don't really know what they are talking about. But then my fear soon dissipated - I never met bad people, I have many friends here, and I haven't felt the disadvantage of living here. My kids love it, too, everything is so quiet and serene." 
their ancestors, but simply their place of residence that predestines them for facing their Jedwabnerness. For them, the enculturation process practically includes the following instructions: learn the culture of seclusion, get to know the true history, feel the tragedy of the locals, share in their common destiny, and all in all, be traumatized yourself! I think it is clear that for newcomers, this is a forced attribution process, which, among other things, proves that trauma definitely can be a constructive definitional element of a community. The culture of seclusion is a knowledge complex that supports the mainstream local trauma narrative, and is a consequence of it, thus trauma itself becomes the basis for determining Jedwabnerness. What are the consequences of the abovementioned problems for an anthropologist? Even though it was a great disadvantage during research that I could not easily (or not at all) share in the knowledge of the locals because I was not a Jedwabner, it was helpful in several situations that they thought it important to educate me in their ways. For this reason, I have somewhat experienced it on my own skin what one must go through in order for the community to accept them (such as a newcomer). Of course, mine was a special situation, because everyone knew that my stay was not permanent so my presence could be dangerous in itself because I came from the public without and returned there, and thus my relationship with the other side was too close. I think that at the beginning of the fieldwork I was taboo violation incarnate, which then eased over time.

It was important that I learn the subtle rules of how I can or cannot talk about the pogrom and the debate. For example, I was not allowed to ask about anything directly - and my close friends instructed me to avoid doing so - because my interviewees would clam up immediately and would only say that they did not know anything, had no opinion, or that they did not want to say anything about it. When we talked about completely different topics, they would often start talking on their own, expressing their opinions, and even found it important to "tell me the truth" even before finding out about my intentions. This contradictory situation may have arisen because, in the former case, they knew that I would use their stories for a potential publication, but in the latter, they tried to override my preconceptions, namely, my thinking of them as monsters. Most actual conversations took place only when I tried to follow my host's instructions, who worked intently to have me not bring shame upon her. She said, for example, that it would greatly ease the distrust against me if I were to go to church with her, so that everyone could see there were common points in our lives, and I was able to understand them. I felt the usefulness of going to church on several occasions. Most Jedwabners attend church regularly, providing me the opportunity to make acquaintances. On the other hand, however, a conflict I once found myself in was resolved by the other party discovering that they had seen me several times in church.

Nonetheless, I was still difficult to classify in the eyes of the locals because I did not fully meet their expectations of the public nor of the locals. This is what the rumors about me that I have heard back and which were trying to infuse meaning into my stay indicate. For example, according to one of the rumors, I moved in with my host family because I was the intended wife for their eldest son, and they also started renovating in recent years because they were expecting my arrival. According to another, I was writing a book 
about the family and their Siberian labor service, because no one has written about it yet, and there were more heroes in Jedwabne than anywhere else in the country. ${ }^{13}$

In my conversations with the people of Jedwabne, it has repeatedly happened (like an absolution for my lack of status) that my conversation partners addressed me as if I were a child. This has been voiced repeatedly ("You have to learn now, so listen carefully to what I'm saying"). According to their reasoning, for one, because I used Polish language like a child, and my knowledge was also only as extensive as a child's. Thus, the narration of the stories was treated as a teaching process, so I think they themselves found the loophole between seclusion from the public and opening up to the public. Furthermore, as part of the teaching process, my closest acquaintances have repeatedly instructed me to adhere to certain behavioral rules. I was told, for example, that it would not look good if I attended the official national commemoration, so if I truly needed to be there, I should go to the cemetery in a roundabout way and not make my presence known. There was also a case when I found out which houses were owned by Jewish families back in those times. I wanted to talk to some of the locals who lived in one of the houses indicated (and perhaps I already knew them), but my friends unanimously said that this was rude, and if I didn't want to be sent away from Jedwabne, I shouldn't ever mention it to anyone.

Nevertheless, this in-between status had and still has a kind of prestige value. For example, locals sometimes find it useful to think that besides knowing their stories, I'm also well-informed about the public sphere (certainly better than they are, because they refuse to read about it, only having a vague knowledge of certain opinions and events). A stellar example of this was when, after screening a pogrom-related interview considered to be fresh, several people sought me out by phone and in person and were interested in what I thought about the case. Except for this, however, the former role association was more common: a half-child who is still learning the language and about being a Jedwabner.

In addition to my position as a researcher, the actual fieldwork practice could be implemented only according to local standards. The interview situation itself cannot be integrated into the culture of seclusion, just as anything else an anthropologist has to do under the label of fieldwork. The greatest archnemesis in Jedwabne is the journalist and the historian; first and foremost, I had to shed that cloak somehow. Interviewing is specifically an act the locals evidently associate with journalists and historians, which is actually explained by the time period surrounding the eruption of the debate. It was important (or in any case, I believe it was imperative) to inform everyone of exactly who I was and what I intended to do during my stay. In a way, I was lucky because no one could take me seriously: to them, I was a 20 -year-old girl, a simple, young female student who in fact doesn't work, doesn't have any major social prestige, so for them, knowing that I was just writing a thesis and later a dissertation about Jedwabne did not cause such a cognitive dissonance as if I wanted to publish a newspaper article or book about the case. Of course, this was not of all-encompassing assistance, but I am convinced that without that role, I wouldn't have had a quarter of the conversation partners that I did.

${ }^{13}$ I must note at this point that I have never concealed my actual interest or what I wanted to say in a lecture or publication. This kind of control/feedback is practically in effect to this day. 
I have already mentioned that during the first half of my fieldwork, most of my acquaintances came from my host's network. This also meant that my host insisted on presenting me in the following way: "This here is Gabi, my dear friend (later my third daughter) from Hungary, an anthropologist, who wants to write a thesis on Jedwabne. She's interested in everything, but especially Siberia". With this, as she said, she wanted to help me, but she also protected herself, because she was the one who let "the public" into her house and she had to compensate for it somehow. The fact that my host reduced my interests mostly to the Siberian deportations, in addition to really helping, has actually raised a number of concerns. On the one hand, I wasn't really interested in it at first (I couldn't have known at the time how important a topic it was), and I was acutely conscious of feeling like I was deceiving people. This was the first serious ethical dilemma I faced, because I thought that if I left it at that, I would really be lying to people, but if I told them that I was really interested in the Jedwabne case, I would discredit my host, which would cause her to lose face. Not to mention that it would probably make continuing my research completely impossible. Eventually, I solved this by never explicitly asking anything specifically about the pogrom or the debate, but since sooner or later it emerged naturally in every conversation, I could cautiously wade through the topic (but only to a certain point, of course). Then, when a conversation ended, I always asked if there was anything I could not use in my thesis, and whether I could write about what they said about the pogrom. Unfortunately, the latter often received a negative response, but I could nonetheless rely on what had been said when I was trying to create an overall picture of Jedwabne, and my conscience remained clear, too.

It is also important to note that conversations were rarely organized, they were usually spontaneous, and one could not prepare for them very well, but if they were organized, they could only be realized after the umpteenth meeting. This is actually also a definitional issue - a spontaneous chat is friendly and confidential, organization, however, is a feature of formal interviews, whose connotations do not exactly fall into the category of friendly, and it comes with serious implications in Jedwabne. I could almost never record and document conversations, and still more rarely did they agree to quoting them verbatim (there are 6-8 people that I quote).

During the fieldwork, I did not interpret most of the above questions exactly in the way I described here, but because my everyday life demanded constant vigilance, concentration, and unbearable self-reflection, I learned the rules of the game relatively soon. In retrospect, however, the way I think about Jedwabne now makes sense. In fact, I am convinced that this continuous compulsion for self-reflection, the countless prohibitions and negotiations fundamentally determined the themes and questions of my research - without these taboos and release attempts, I never would have learned anything important about the "real" Jedwabne.

The taboo issue is fundamentally a methodological basis and a moral shackle at once; nevertheless, the often severe prohibitions are not necessarily of the devil, and not necessarily limitations by definition, but primarily integral parts of the field, telling us a lot about the subject of our research. I'd like to close my study with the thoughts of Anna Losonczy: 
Reporter: "At one time you wrote that this method was in fact the science of silence."

Anna Losonczy: "I didn't know this as a young researcher. I was convinced, like I think other young ethnographers, too, that the time was short, the material enormous, the compulsion to understand raging, so people had to be bombarded with different issues from morning to night. The painter Georges Braque once said that explanations and questions wear out the truth. I wasn't familiar with this idea at that time, but intuitively I realized that the responses to my questions were always just products of those questions. If, on the other hand, I just watch - listen to what people are talking about and go where they go, and I speak and make my presence known as little as possible during these gatherings, and what's more, if I let people ask me about things - after all, I'm not a natural scientist, the subjects of my research are human beings who have opinions and a right to ask questions - then the whole thing becomes much more interesting. And so, I abandoned this somewhat police-like questioning method focused on specific results, and I understood that my profession is the most beautiful profession in the world." ${ }^{14}$

\section{REFERENCES CITED}

Alexander , Jeffrey C.

2012 Trauma. A Social Theory. Cambridge: Polity Press.

AleXANDER, Jeffrey C. et al. (eds.)

2004 Cultural Trauma and Collective Identity. Berkeley (CA): University of California Press.

Bikont, Anna

2004 My z Jedwabnego [We from Jedwabne]. Warsaw: Prószyński i S-ka.

Caruth, Cathy - Felman, Shoshana

1991 Trauma: Explorations in Memory. Baltimore: Johns Hopkins University Press.

Chagnon, Napoleon

1968 Yanomamö: The Fierce People. New York: Holt, Rinehart and Winston.

2014 Noble Savages: My Life Among Two Dangerous Tribes - The Yanomamö and the Anthropologists. New York: Simon \& Schuster.

FulBrooK, Mary

1999 A német nemzeti identitás a holokauszt után [German National Identity after the Holocaust]. Cambridge: Polity Press

GlowaCKA, Dorota - ZYLINSKA, Joanna

2007 Imaginary neighbors. Toward an ethical community. Nebraska: Board of Regents of the University of Nebraska.

GonTARCZyK, Piotr

2001 Gross kontra fakty. Kolejny głos na temat książki "Sąsiedzi” opisującej mord na Żydach w Jedwabnem [Gross versus Facts. Another Viewpoint on the Book "Neighbors" Describing the Murder of Jews in Jedwabne]. Gazetta

${ }^{14}$ Source: http://epa.oszk.hu/00700/00775/00016/318-328.html (accessed: September 20, 2017). 
Wyborcza 2007:07 http://www.naszawitryna.pl/jedwabne_253.html (accessed November 20, 2015).

Gross, Jan Tomas

2000 Sasiedzi. Historia zagłady żydowskiego miasteczka [Neighbors. The History of the Destruction of a Jewish Town]. Pogranicze: Sejny.

GYÁNI, Gábor

2006 Emlékezet és felejtés mint politikai stratégia [Memory and History as Political Strategy]. Kritika 2006(9):6-10.

2012 Kulturális trauma: adott vagy teremtett [Cultural Trauma: A Given or a Fabrication]. In DÁnél, Mónika - Fodor, Péter - L. VARgA, Péter (eds.)

Heller, Ágnes Event - Trauma - Publicity, 38-58. Budapest: Ráció kiadó.

2006 Trauma. Budapest: Múlt és Jövő.

JANOWSKI, Maciej

2012 Jedwabne, July 10, 1941: Debating the History of a Single Day. In MiLler, Alexei - Lipman, Maria (eds.) The Convolutions of Historical Politics. Budapest-New York: CEU Press.

KaCZINSKI, Andrzej

2000 Całopalenie. W Jedwabnem zagłady Żydów Niemcy dokonali polskimi rękami [Holocaust. In Jedwabne, the Germans Executed the Jews with Polish Help]. Rzeczpospolita 2000(05).

2000 Oczyszczenie pamięci [The Purification of Memory]. Rzeczpospolita 2000(05)

KAPRALSKI, Sławomir

2006 The Jedwabne Village Green? The Memory and Counter-Memory of the Crime. History and Memory 2006(1):179-194.

KisAnTAL, Tamás

2009 Túlélö történetek. Ábrázolásmód és történetiség a holokauszt müvészetében [Survivor Stories. Modes of Representation and Historicity in the Art of the

KovÁcs, Éva Holocaust]. Budapest: Kijárat.

1998 'I Have a Certificate of Not Being Anti-Semite' - Identity of a 'Social Jew': Its Roots in Life History. East European Review, Special Issue 1998(II).

2008 Ártatlan tettesek - néma közösségek [Innocent Culprits - Silent Communities]. 2000 2008(6):10-18.

MészÁros, Csaba - VArgYas, Gábor

2016 Gyüjtés és terepmunka a néprajztudományban [Fieldwork in Ethnographic Scholarship]. Ethno-lore 33:9-17.

NAGY, Zoltán

2017 Konfliktus és terepmunka [Conflict and Fieldwork]. Ethno-lore. 34:129-145.

Polonsky, A. - Michlic, J. B. (eds.)

2004 The Neighbors Respond: The Controversy over the Jedwabne Massacre in Poland. Princeton, New Jersey: Princeton University Press.

RÉGI, Tamás

2016 A terepmunka mint mágia [Fieldwork as Magic]. Ethno-lore 33:299-310. 
RoseNFELD, Alvin H.

1980 A Double Dying: Reflections on Holocaust Literature. Indiana University Press.

SÁNTHA, István

2016 A Napsugár története. Találkozásaink története [The History of Sunshine. The History of Our Encounters]. Ethno-lore 33:311-330.

TODOROv, Tzvetan

2005 A rossz emlékezete, a jó kisértése [Memory of the Bad, Temptation of the Good]. Mérlegen a XX. század. Transl.: József Bethlen. Budapest: Napvilág.

VARGYAS, Gábor

2016 Fieldwork, Politics, Ethics. In Mészéros, Csaba - VARgyas, Gábor (eds.) Fieldwork in Ethnographic Scholarship. Ethno-lore 33:331-355. Budapest: MTA Institute of Ethnology.

Wolentarska-Ochman, Eva

2016 Collective Remembrance in Jedwabne. Unsettled Memory of World War II in Postcommunist Poland. History and Memory 200(18):152-178.

Gabriella Tuboly-Vincze is a PhD candidate at the University of Pécs. Her major field of interest is the anthropology of social trauma. Between 2012-2018, she studied a special traumatic memory in Jedwabne (Poland), focusing on the local narratives and the potential influences of public memories connected with the local history of World War II. E-mail:vinczegabcsi87@gmail.com 